\title{
Culturable bacteria in Himalayan glacial ice in response to atmospheric circulation
}

\author{
S. Zhang ${ }^{1}$, S. Hou ${ }^{1}$, X. Ma ${ }^{1,2}$, D. Qin ${ }^{1}$, and T. Chen ${ }^{1}$ \\ ${ }^{1}$ Laboratory of Cryosphere and Environment, Cold and Arid Regions Environmental and Engineering Research Institute, \\ Chinese Academy of Sciences, Lanzhou 730000, China \\ ${ }^{2}$ School of Life Science, Lanzhou University, Lanzhou 730000, China
}

Received: 7 March 2006 - Published in Biogeosciences Discuss.: 26 June 2006

Revised: 27 September 2006 - Accepted: 18 December 2006 - Published: 10 January 2007

\begin{abstract}
Only recently has specific attention been given to culturable bacteria in Tibetan glaciers, but their relation to atmospheric circulation is less understood yet. Here we present the results of culturable bacteria preserved in an ice core drilled from the East Rongbuk (ER) glacier, Himalayas. The average concentrations of culturable bacteria are 5.0,

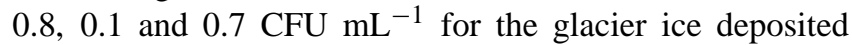
during the premonsoon, monsoon, postmonsoon and winter seasons, respectively. The high concentration of culturable bacteria in ER glacier deposited during the premonsoon season is attributed to the transportation of continental dust stirred up by the frequent dust storms during spring. This is also confirmed by the spatial distribution of culturable bacteria in Tibetan glaciers. Continental dust originated from the Northwest China accounts for the high abundance of culturable bacteria in the northern Tibetan Plateau, while monsoon moisture exerts great influence on culturable bacteria with low abundance in the southern plateau. The numbers of representatives with different ARDRA patterns from RFLP analysis are 10, 15, 1 and 2 for the glacial ice deposited during the premonsoon, monsoon, postmonsoon and winter seasons, respectively, suggesting that culturable bacteria deposited in ER glacier during monsoon season are more diverse than that deposited during the other seasons, possibly due to their derivation from both marine air masses and local or regional continental sources, while culturable bacteria deposited during the other seasons are from only one possible origin that is transported by westerlies. Our results show the first report of seasonal variations of abundance and species diversity of culturable bacteria recovered from glacial ice in the Himalayas, and we suggest that microorganisms in Himalayan ice might provide a potential new proxy for the reconstruction of atmospheric circulation.
\end{abstract}

Correspondence to: $\mathrm{S}$. Hou

(shugui@1zb.ac.cn)

\section{Introduction}

Bacteria in glacial ice have been studied for polar regions (Dancer et al., 1997; Abyzov et al., 1998; Castello et al., 1999; Willerslev et al., 1999), and the Tibetan plateau (Christner et al., 2000; Zhang et al., 2003; Yao et al., 2006). Abyzov et al. (1998) reported that the amount of bacteria in melt water samples of the Antarctic Vostok ice core was closely correlated with mineral concentrations at the time of deposition. This kind of correlation also exists in the Tibetan Plateau (Zhang et al., 2003). Dust in glacial ice may influences physiological state of microorganisms, because it might absorb solar radiation and form small water bulbs in glacial ice, and as a result activities of microorganisms can be supported (Priscu et al., 1998). Yao et al. (2004) and Wu et al. (2004) pointed out that high dust concentrations correlated with cold periods in the Tibetan ice cores. The mechanism might be that low temperature will not only cause the expansion of the dust source area, but also increase the wind speed, resulting in more terrestrial dust input into the atmosphere. On the basis of this logic and at a relatively long timescale, Yao et al. (2006) studied the microorganisms of the Malan ice core drilled from the central Tibetan Plateau and demonstrated that more microorganisms were associated with cold periods while few microorganisms were associated with warm periods. In the northern and central Tibetan Plateau, the temperature can be represented by the ice core $\delta^{18} \mathrm{O}$ variation (Tian et al., 2001).

Four samples collected from an ice core of the ER glacier, Himalayas, were investigated for concentration and species diversity of culturable bacteria, and their possible origins based on 16S rRNA sequences. We try to extend our current understanding of seasonal and spatial variations of culturable bacteria in the Tibetan Plateau. In particular, we bring together microbiological studies and $\delta^{18} \mathrm{O}$ analysis of the ice core samples to deduce the relationship between concentration, diversity and sources of culturable bacteria and atmospheric circulation.

Published by Copernicus GmbH on behalf of the European Geosciences Union. 


\section{Materials and methods}

\subsection{Ice core collection}

A $40.87 \mathrm{~m}$ ice core was recovered from the saddle of the ER glacier $\left(28^{\circ} 01^{\prime} 05^{\prime \prime} \mathrm{N}\right.$; $86^{\circ} 57^{\prime} 52^{\prime \prime} \mathrm{E}$; $6518 \mathrm{~m}$ a.s.1.) during 2002. This glacier covers a total area of $48.45 \mathrm{~km}^{2}$ with a length of $14 \mathrm{~km}$. Its equilibrium line of $6250 \mathrm{~m}$ above sea level is among the highest in the world. Borehole temperature is $-9.6^{\circ}$ at $10 \mathrm{~m}$ depth, ensuring preservation of a climatic record. At the drilling site, the annual net balance is about $0.5 \mathrm{~m}$ water equivalent (Kang et al., 2002). The core (diameter $0.094 \mathrm{~m}$ ) was recovered using an electromechanical drill in a dry hole. Visible stratigraphy showed no hiatus features within the whole core. Ice core was maintained below $-5^{\circ}$ from the time of drilling until analysis.

The $0.57 \mathrm{~m}$ ice core from $40.30 \mathrm{~m}$ to $40.87 \mathrm{~m}$ depth was cut axially and quasi-equally into four sections. At the saddle of ER glacier, the present average annual net accumulation is about $500 \mathrm{~mm}$ water equivalent as determined from snowpits and a stake accumulation network established during a reconnaissance in May 1998. For an $80.4 \mathrm{~m}$ ice core recovered at $6450 \mathrm{~m}$ of ER glacier, Kang et al. (2002) counted 152 annual layers by the high-resolution (average 12 samples per year) major ion records, giving an accumulation history of 0.42 $0.60 \mathrm{~m}$ per year for the period 1846-1997 AD. This, together with the seasonality of $\delta^{18} \mathrm{O}$, suggests that these four samples represent roughly four seasons of one whole year.

\subsection{Decontamination}

Ice core decontamination and sampling procedures were established according to Willerslev et al. (1999) and Zhang et al. (2001) with minor modification. For all sampling procedures, plastic tools were exposed to a germicidal UV lamp for $\geq 30 \mathrm{~min}$ and ferric and ceramic tools were autoclaved. Prior to analysis, an outer $0.01 \mathrm{~m}$ annulus was sliced from each sample with sterile stainless steel scalpels. The inner discs were rinsed in the $4^{\circ}$ solution of $2.5 \%$ iodine and $0.1 \%$ bromo-geramine for $2 \mathrm{~min}$. After finally rinsed with cold deioned sterile water 3 times (melting away about $2 \mathrm{~mm}$ of the exterior surfaces), the samples were placed into sterile glass beakers and allowed to melt completely at $4^{\circ}$ in the dark.

To make sure that the inner part of ice core was free from contamination, we investigated changes in the concentrations of culturable bacteria from the outside to the inside of a $0.10 \mathrm{~m}$ ice core sample from $40.20 \mathrm{~m}-40.30 \mathrm{~m}$ of the $40.87 \mathrm{~m}$ ice core. The result showed that bacterial concentrations are fairly stable when three successive veneer layers (about 0.01 $\mathrm{m}$ ) were chiseled off, indicating that external contamination has not penetrated to the inner part. The approach verified, to a certain extent, the authenticity of the microbiological results obtained from the ice core samples. In addition, the sterile double distilled water used to rinse the 4 samples was collected in this research and was inoculated onto R2A and PYGV media as control. The results demonstrated undetectable level of contamination by the above procedures employed.

\subsection{Bacterial isolation and count}

Samples of melt water $(200 \mathrm{~mL})$ from the ice cores were filtered at room temperature (about $25^{\circ}$ ) through polycarbonate filters (Whatman) with $0.22 \mu \mathrm{m}$ pore size, and the particulates collected were resuspended in $2.0 \mathrm{~mL}$ phosphatebuffered saline (Xiang et al., 2005a). Aliquots of these suspensions were spread onto the surface of agar-solidified media PYGV (http://www.dsmz.de/media/med621.htm) and R2A (http://www.dsmz.de/media/med830.htm) containing low levels of nutrients, and duplicate plates were incubated aerobically at $4^{\circ}$ and $20^{\circ}$ for about $90 \mathrm{~d}$ and $30 \mathrm{~d}$ respectively. Concentrations of culturable bacteria were estimated by counting the average CFU (colony formation units) per millilitre on each agar plate. Colonies with different morphologies were checked for purity by streaking on plates of the same medium, and stored in glycerol at $-70^{\circ}$.

\subsection{DNA extraction}

Total DNA of the isolated bacteria was extracted according to the method described by Zhou et al. (1996). Bacterial colonies were resuspended in $13.5 \mathrm{~mL}$ of DNA extraction buffer (100 mM Tris-HCl (pH 8.0), $100 \mathrm{mM}$ sodium EDTA ( $\mathrm{pH} 8.0), 100 \mathrm{mM}$ sodium phosphate $(\mathrm{pH} 8.0), 1.5 \mathrm{M} \mathrm{NaCl}$, $1 \% \mathrm{CTAB})$, and $100 \mathrm{~mL}$ of proteinase $\mathrm{K}(10 \mathrm{mg} / \mathrm{mL})$ in centrifuge tubes, by horizontal shaking at $225 \mathrm{rpm}$ for $30 \mathrm{~min}$ at $37^{\circ}$. Afterwards, $1.5 \mathrm{~mL}$ of $20 \%$ SDS was added, and the samples were incubated in a $65^{\circ}$ water bath for $2 \mathrm{~h}$ with gentle end-over-end inversions every 15 to $20 \mathrm{~min}$. The supernatants were collected after centrifugation at $6000 \times g^{* 1}$ for $10 \mathrm{~min}$ at room temperature, and transferred into $50 \mathrm{~mL}$ centrifuge tubes. Supernatants from the extractions were combined with an equal volume of chloroform-isoamyl alcohol $(24: 1, \mathrm{vol} / \mathrm{vol})$. The aqueous phase was recovered by centrifugation and precipitated with 0.6 volume of isopropanol at room temperature for $1 \mathrm{~h}$. The pellet of crude nucleic acids was obtained by centrifugation at $16000 \times g$ for $20 \mathrm{~min}$ at room temperature, washed with cold $70 \%$ ethanol, and resuspended in sterile deionized water, given a final volume of $500 \mathrm{~mL}$.

\footnotetext{
${ }^{1}$ Relative centrifugal force ( $\mathrm{RCF}$ ) is the measurement of the force applied to a sample within a centrifuge. This can be calculated from the speed (RPM) and the rotational radius $(\mathrm{cm})$ using the following calculation: $\mathrm{RCF}=0.00001118 \times r \times N^{2}$, where $r=$ rotational radius (centimetre, $\mathrm{cm}$ ), $N=$ rotating speed (revolutions per minute, RPM).
} 
2.5 PCR amplification, Restriction Fragment Length Polymorphism (RFLP) analysis, and sequencing of amplified 16S rRNA

Isolates' 16S rRNA from the recovered bacteria was amplified by PCR using the oligonucleotide primers PB36 (5'-AGAGTTTGATCCTGGCTCAG-3') and PB38 (5'-CGGTTACCTTGTTACGACTT-3'), corresponding to Escherichia coli positions 8-27 and 1511-1492, respectively. PCR was carried out in a final volume of $25 \mu \mathrm{L}$ using $5 \mu \mathrm{L}$ template DNA, $2.0 \mathrm{mM} \mathrm{MgCl}_{2}, 0.2 \mathrm{mM}$ each dNTP, $0.2 \mu \mathrm{M}$ each primer, and $1 \mathrm{U}$ Taq polymerase with 1 volume of the supplied buffer (MBI). Reactions were performed in the thermocycler (GeneAmp PCR System 2700, Applied Biosystems) with the following cycling parameters: $94^{\circ}$ for $1 \mathrm{~min}$ for an initial denaturation, followed by 30 cycles of $94^{\circ}$ for $1 \mathrm{~min}, 58^{\circ}$ for $1 \mathrm{~min}$, and $72^{\circ}$ for $1.5 \mathrm{~min}$, and a final incubation at $72^{\circ}$ for $10 \mathrm{~min}$.

The PCR products were digested with one of four base pair cleaving restriction endonuclease Hae III and Hind6I (MBI) according to the supplier's instructions. Isolates were grouped together on the basis of the restriction fragment patterns.

The 16S rRNA products representing each distinct pattern were further purified, sequenced using a state-of-the-art ABI 3730XL96 capillary sequencer with internally nested primers 27F (GGTAGAGTTTGATCCTGGCTCAG), 517F (CCAGCAGCCGCGGTAAT) and 907F (AAACTCAAATGAATTGACGGG) to obtain overlapping sequences.

The single stranded 16S rRNA gene sequences of the bacteria were matched with those from a Blast search of the National Center for Biotechnology Information (NCBI) database (Altschul et al., 1990). The gene sequences from the bacteria were aligned with reference sequences obtained from GenBank databases by using the Clustal X program (Thompson et al., 1997). The BioEdit alignment was used in maximum-likelihood and distance analyses utilizing the Mega ((Molecular Evolutionary Genetics Analysis, Version 3.0) package (Kumar and Tamura, 1993).

\subsection{Analyses of stable oxygen isotope ratios}

The sliced outer $1 \mathrm{~cm}$ annulus from the 4 samples were collected and placed into pre-cleaned high density polyethylene containers, respectively, for analyses of stable oxygen isotope ratios $\left(\delta^{18} \mathrm{O}\right)$, which were performed using a Finnigan MAT-252 mass spectrometer (accuracy $0.05 \%$ ). The results were expressed as the relative deviation of heavy isotope content of Standard Mean Ocean Water (SMOW).
Table 1. Concentrations of culturable bacteria under different culture media and temperatures.

\begin{tabular}{|c|c|c|c|c|c|c|c|c|c|}
\hline \multicolumn{2}{|c|}{ Culturable conditions } & \multicolumn{2}{|c|}{ I } & \multicolumn{2}{|c|}{ II } & \multicolumn{2}{|c|}{ III } & \multicolumn{2}{|c|}{ IV } \\
\hline \multirow{2}{*}{$\mathrm{R} 2 \mathrm{~A}$} & $20^{\circ} \mathrm{C}$ & 7.0 & 5.6 & 0.6 & 1.2 & 0.3 & 0.1 & 0.6 & 1.1 \\
\hline & $4{ }^{\circ} \mathrm{C}$ & 4.3 & 5.2 & 0.7 & 0.8 & 0.2 & 0.0 & 0.9 & 0.3 \\
\hline \multirow{2}{*}{ PYGV } & $20{ }^{\circ} \mathrm{C}$ & 5.4 & 6.0 & 1.2 & 0.8 & 0.1 & 0.0 & 1.5 & 1.0 \\
\hline & $4{ }^{\circ} \mathrm{C}$ & 3.2 & 3.1 & 0.6 & 0.8 & 0.1 & 0.1 & 0.3 & 0.1 \\
\hline
\end{tabular}

\section{Results and discussion}

3.1 Spatial distribution of culturable bacteria on the Tibetan Plateau

Concentration of culturable bacteria in the ER glacier is between 0-7.0 CFU mL $\mathrm{mL}^{-1}$ (colony forming units per milliliter) (Table 1), while that of other glaciers from the northern Tibetan Plateau (Guliya, Muztagh Ata and Malan) show a much broad range (Christner et al., 2000; Zhang et al., 2001; Xiang et al., 2005b, Fig. 1). Especially, the concentration maximum of culturable bacteria in ER is one order of magnitude lower than that of other Tibetan glaciers. Christner (2002) suggested that glaciers in the Tibetan Plateau, due to its proximity to locations with substantial vegetation and exposed soils, which serve as major sources of atmospheric particles entrapped higher concentration of culturable bacteria than Antarctic or Greenland ice sheets. Although this is true for Guliya (Christner et al., 2000), Muztagh Ata (Xiang et al., 2005b) and Malan glaciers (Zhang et al., 2001; Yao et al., 2006), concentration of culturable bacteria in the ER glacier is among the concentration level of the polar region (Fig. 1).

Guliya, Muztagh Ata and Malan glaciers are in a continental climate domain. Impurity within these glaciers is dominated by the influx of continental dust derived from the surrounding arid or semi-arid regions of central Asia. To the contrary, impurity in the Himalayan glaciers is strongly affected by maritime aerosols (Wake et al., 1994). Xiao et al. (2002) showed that the concentration of major ions in the north Tibetan Plateau was 6-30 times higher than that in the south. In fact, microparticle in ER (unpublished data) is two orders of magnitude lower than that in Guliya ice core (Wu et al., 2004). The common spatial distribution of culturable bacteria, major ions and microparticle in the Tibetan glaciers implies that they are influenced by similar environmental factors including dust and moisture sources, monsoon circulation.

\subsection{Seasonality of concentrations of culturable bacteria}

We make use of $\delta^{18} \mathrm{O}$ of the samples to infer their deposition seasons. Stable isotopes in precipitation are dependent on 


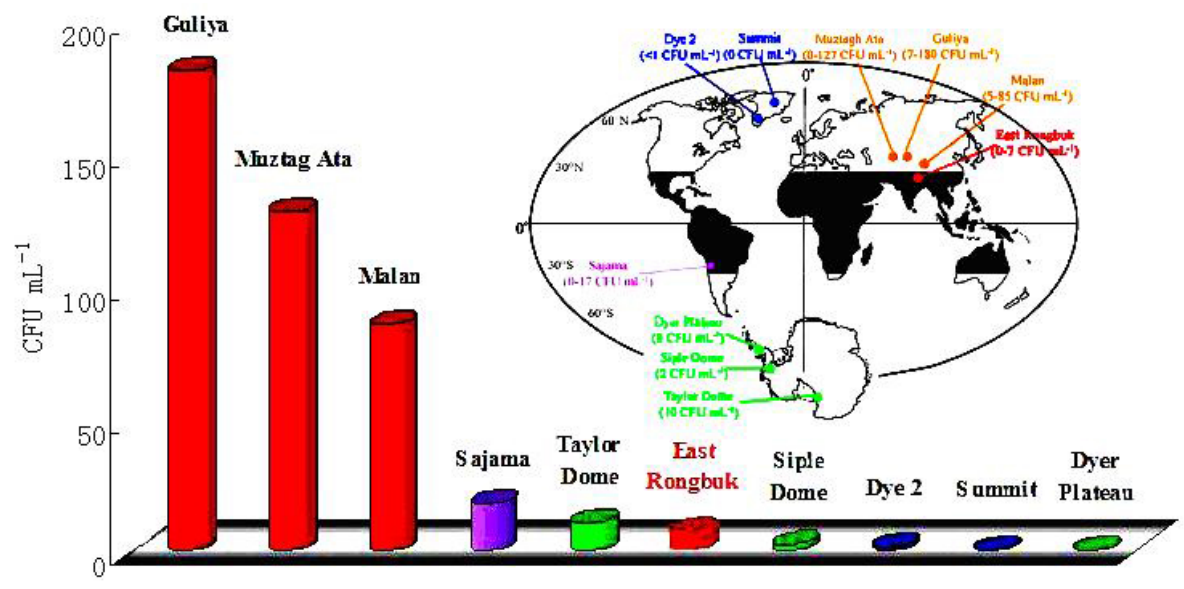

Fig. 1. Concentration of culturable bacteria recovered from the ER glacier (red) compared with other Tibetan (orange), Sajama, Bolivia (purple), Arctic (blue) and Antarctic (green) ice cores. Inset shows the location of sampling sites (modified from Christner et al., 2000).

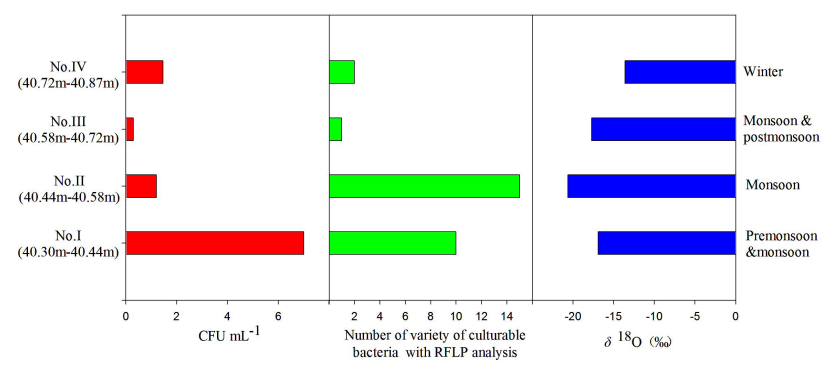

Fig. 2. Seasonal variation of the average concentrations of culturable bacteria (CFU mL ${ }^{-1}$ ), number of culturable bacteria with different ARDRA patterns with RFLP analysis and $\delta^{18} \mathrm{O}(\% o)$.

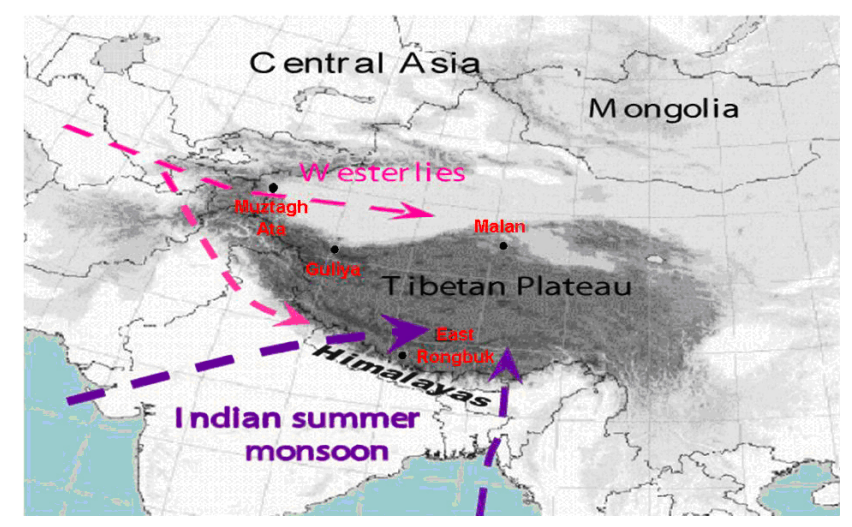

Fig. 3. Circulation systems influencing the study area (Indian Summer Monsoon and Westerlies in winter).

many factors from the origins of moisture, transport of moisture, moisture recycling and precipitation processes. In the Himalayan region, the mechanism controlling the stable isotope in precipitation is closely related to the monsoon mois- ture transport. The degree of distillation is mainly driven by the progressive moisture depletion as the marine air masses move inland or cool down towards the high Himalayas and by vertical movements due to convective activity (Tian et al., 2001). Strong monsoon activity results in high precipitation rates and depletes the heavy isotopes by fractionation processes (Tian et al., 2003). Therefore, $\delta^{18} \mathrm{O}$ depletion occurs during the summer monsoon season, and $\delta^{18} \mathrm{O}$ enrichment during the winter dry season (Marinoni et al., 2001; Thompson et al., 2000; Zhang et al., 2005). This can be used as an indicator of seasonality of the glacial snow/ice layers. Thus Sample No. II with the lowest $\delta^{18} \mathrm{O}(-20.65 \%$ ) is confirmed to be deposited in monsoon season (Fig. 2), while Sample No. IV with the highest $\delta^{18} \mathrm{O}(-13.60 \%$ ) was deposited in winter. Accordingly, Samples No. I and No. III were deposited roughly during the premonsoon and the postmonsoon seasons, respectively.

From Table 1, the average concentrations of culturable

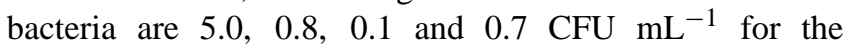
glacier ice deposited during the premonsoon (Sample No. I), monsoon (Sample No. II), postmonsoon (Sample No. III) and winter (Sample No. IV) seasons, respectively (Fig. 2). ANOVA contrasts of between-subjects effects of sample, temperature and medium on the average concentrations of culturable bacteria (Table 2) indicated that the interaction between sample vs. temperature and concentrations of culturable bacteria was significant at $p<0.05$. Between-subjects analyses for the main effect of sample and temperature also revealed significant differences for concentrations of culturable bacteria at $\mathrm{p}<0.05$. With posthoc pairwise comparison, concentration of culturable bacteria recovered from Sample No. I was significantly higher than that from the other three samples at $\mathrm{p}<0.05$ (Table 3 ).

This seasonality of culturable bacteria is connected to the atmospheric circulation on the Tibetan Plateau (Fig. 3). 
Table 2. One-way ANOVA contrasts of variables between treatments within the average concentrations of culturable bacteria.

\begin{tabular}{lllllllll}
\hline Source & $\begin{array}{l}\text { Type III Sum } \\
\text { of Squares }\end{array}$ & df & $\begin{array}{l}\text { Mean } \\
\text { Square }\end{array}$ & $F$ & $\begin{array}{l}P \\
\text { Squared }\end{array}$ & $\begin{array}{l}\text { Partial Eta } \\
\text { Parameter }\end{array}$ & $\begin{array}{l}\text { Noncent. } \\
\text { Power }\end{array}$ & $\begin{array}{l}\text { Observed } \\
\text { Corrected Model }\end{array}$ \\
Intercept & 132.158 & 15 & 8.811 & 60.431 & .000 & .983 & 906.471 & 1.000 \\
Samples & 88.512 & 1 & 88.512 & 607.101 & .000 & .974 & 607.101 & 1.000 \\
Temperature & 119.707 & 3 & 39.902 & 273.691 &. $\mathbf{0 0 0}$ & .981 & 821.072 & 1.000 \\
Medium & 4.292 & 1 & 4.292 & 29.442 & $\mathbf{. 0 0 0}$ & .648 & 29.442 & .999 \\
Sample vs. temperature & .644 & 1 & .644 & 4.418 & .052 & .216 & 4.418 & .506 \\
Sample vs. medium & 4.951 & 3 & 1.650 & 11.320 &. $\mathbf{0 0 0}$ & .680 & 33.960 & .995 \\
Temperature vs. medium & 1.752 & 3 & .584 & 4.005 & .026 & .429 & 12.016 & .732 \\
Sample vs. temperature vs. medium & .387 & 1 & .387 & 2.656 & .123 & .142 & 2.656 & .335 \\
Error & .424 & 3 & .141 & .969 & .432 & .154 & 2.907 & .216 \\
Total & 2.333 & 16 & .146 & & & & & \\
Corrected Total & 223.002 & 32 & & & & & & \\
\hline
\end{tabular}

F-values and P-values are presented. Significant comparisons are indicated with bold P-values.

Computed using alpha $=0.05$

R Squared $=.983($ Adjusted R Squared $=.966)$

Table 3. Post hoc test results of multiple comparisons with Tamhane analysis among the 4 samples.

\begin{tabular}{|c|c|c|c|c|c|c|}
\hline \multicolumn{2}{|c|}{ Samples } & \multirow{2}{*}{ Mean Difference (I-J) } & \multirow{2}{*}{ Std. Error } & \multirow{2}{*}{ Sig. } & \multicolumn{2}{|c|}{$95 \%$ Confidence Interval } \\
\hline & & & & & Lower Bound & Upper Bound \\
\hline \multirow{3}{*}{ I } & II & 4.1350 & .48502 & .000 & 2.4147 & 5.8553 \\
\hline & III & 4.8663 & .47888 & .000 & 3.1384 & 6.5941 \\
\hline & IV & 4.2613 & .50593 & .000 & 2.5490 & 5.9735 \\
\hline \multirow{3}{*}{ II } & I & -4.1350 & .48502 & .000 & -5.8553 & -2.4147 \\
\hline & III & .7313 & .08956 & .000 & .4318 & 1.0307 \\
\hline & IV & .1262 & .18618 & .987 & -.4772 & .7297 \\
\hline \multirow{3}{*}{ III } & I & -4.8663 & .47888 & .000 & -6.5941 & -3.1384 \\
\hline & II & -.7313 & .08956 & .000 & -1.0307 & -.4318 \\
\hline & IV & -.6050 & .16955 & .047 & -1.2037 & -.0063 \\
\hline \multirow{3}{*}{ IV } & I & -4.2613 & .50593 & .000 & -5.9735 & -2.5490 \\
\hline & II & -.1262 & .18618 & .987 & -.7297 & .4772 \\
\hline & III & .6050 & .16955 & .047 & .0063 & 1.2037 \\
\hline
\end{tabular}

Note: The mean differences significant at the 0.05 level are indicated with bold P-values.

During summer, low pressure over the surface of the plateau (Tibetan Low) induces a supply of moist and warm air from the Indian Ocean to the continent (summer monsoon), meanwhile, in the upper troposphere the Southern Asian High centers over the Tibetan Plateau and drives air mass moving out of the plateau (Wu and Zhang, 1998; Li, 2002). Then, there is South Asian Monsoon Cell (inverse to the Hadley Cell) formed between the Tibetan Plateau and the Indian Ocean, which transports moisture into the Tibetan Plateau from Indian Ocean in the lower troposphere and sends air back in the upper troposphere (Zhou, 1997; Li, 2002). In winter, high pressure (Tibetan High) drives cold and dry air moving out of the plateau (winter monsoon) in the lower troposphere (Bryson, 1986; Tang, 1998). While in the middle and up- per troposphere, subtropical jet streams flow south and north of the plateau. In the surface of the plateau, anticyclone is dominant in the north of the plateau, while cyclone in the south of the plateau. In the region where our ice core was recovered, precipitation is caused by moisture transported by summer Indian monsoon and/or by local moisture from short distance convective air mass during summer (June to September), and moisture is transported by westerlies during winter and spring (October to May). Therefore, the core section containing the highest amount of dust corresponds to spring precipitation, while the summer Indian Monsoon contributes to a decrease in atmospheric dust loading (Kang et al., 2000).

From the above, it is suggested that Sample No. I with 


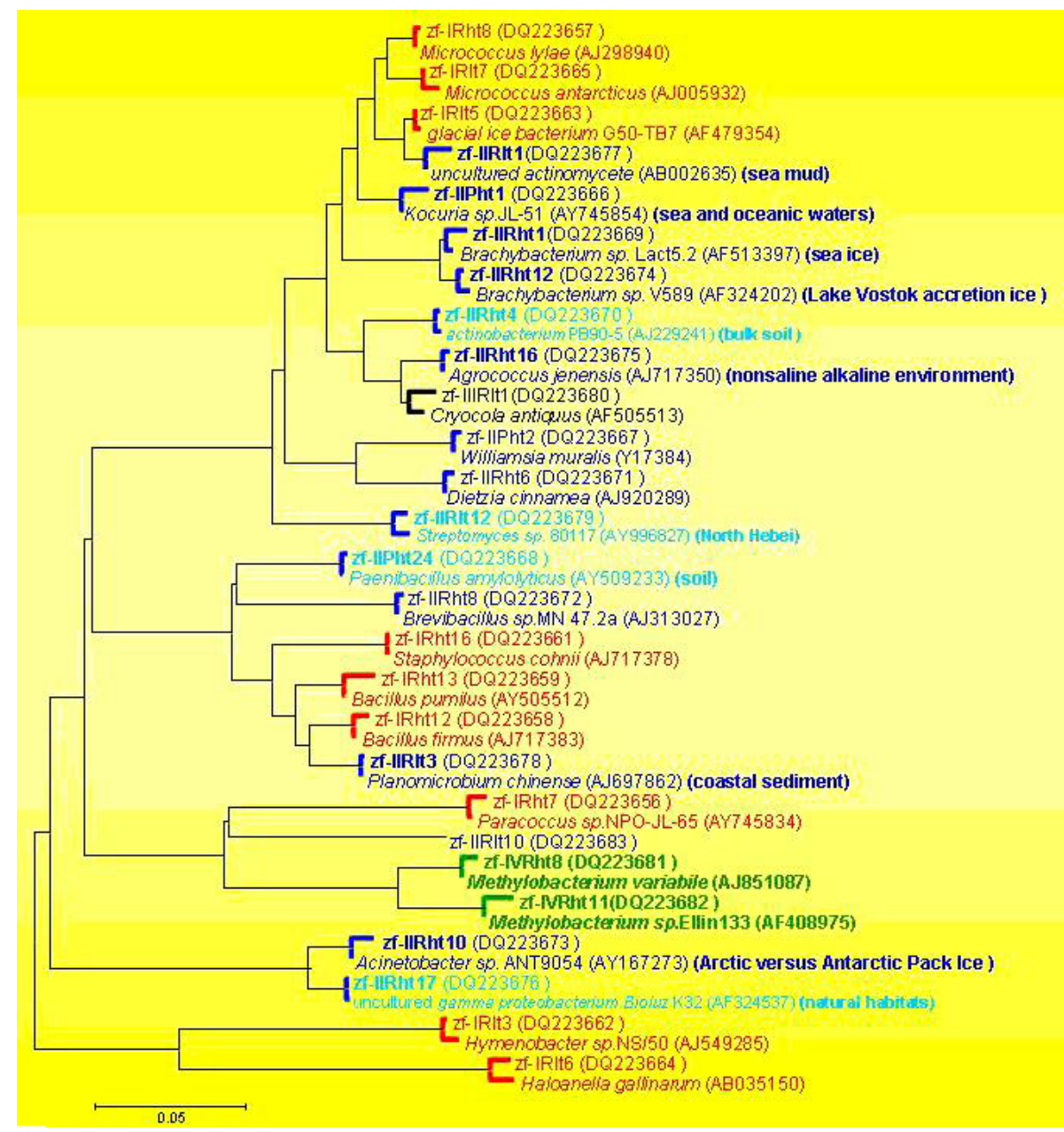

Fig. 4. Maximum Parsimony phylogeny of culturable bacterial $16 \mathrm{~S}$ rRNA sequences amplified from the four samples. The culturable bacteria were nominated as: $\mathrm{R}$ and $\mathrm{P}$ refer to isolates recovered from culture medium R2A and PYGV, respectively. I, II, III and IV correspond to isolates recovered from Sample No. I (red), No. II (blue), No. III (black) and No. IV (green), respectively. ht and lt correspond to isolates recovered from $20^{\circ}$ and $4^{\circ}$, respectively. Previously unpublished sequences are deposited in GenBank under accession numbers DQ223656-DQ223683, except DQ223659.

the highest abundance of culturable bacteria was deposited during premonsoon season, a period consistent to the highest atmospheric dust loading transported by westerlies (Kang et al., 2000). The close correlation between concentration of culturable bacteria and dust was also identified in Vostok ice core (Abyzov et al., 1998; Priscu et al., 1998, 1999) and Malan Ice Cap (Zhang et al., 2001; Yao et al., 2006).

\subsection{Seasonality of culturable bacteria sources}

From the results of Restriction Fragment Length Polymorphism (RFLP), the numbers of representatives with different ARDRA (amplified rRNA restriction analysis) patterns are $10,15,1$ and 2 for the glacial ice deposited during the premonsoon (Sample No. I), monsoon (Sample No. II), postmonsoon (Sample No. III) and winter (Sample No. IV) seasons, respectively (Fig. 2), indicating that Sample No. II has the highest variety of culturable bacteria among the four samples. Statistics suggests that the numbers of different ARDRA patterns reached statistical significance based on Chi-Square test (Table 4). It is suggested culturable bacteria deposited during monsoon season originate from either marine air masses and/or continental air fluxes, whereas culturable bacteria deposited during the other seasons are from only continental environment. However, it's worthy pointing out that the samples may not correspond exactly to their specific seasons due to coarse sampling resolution. For instance, Sample No. I may include partly culturable bacteria deposited during monsoon season, resulting in its relatively higher variety of culturable bacteria than Samples III and IV. Such a seasonality of the variety of culturable bacteria is also prominent for major ions of an $80 \mathrm{~m}$ ice core recovered from the ER glacier (Kang et al., 2002). 
16S rRNA sequences of the representatives (Fig. 4) shows that nearly half of the isolates with different ARDRA (amplified rRNA restriction analysis) patterns and recovered from Sample No. II are associated with marine environment, implying their sources of monsoon air masses. Sequence zf-IIPht1 shares 98\% sequence similar to that of Kocuria palustris (Y16263), retrieved from marine (Jiao et al., unpublished). Sequence zf-IIRht1 is a deep lineage within Brachybacterium sp. Lact5.2 (AF513397) from Arctic sea ice (Groudieva et al., 2004), with 98\% similarity. zf-IIRht10 is affiliated with genera in the linage of Acinetobacter sp. ANT9054 (AY167273) from Arctic versus Antarctic Pack Ice (Brinkmeyer et al., 2003). Sequence zf-IIRht12 is most similar to that of Brachybacterium sp. V589 (AF324202) from Lake Vostok accretion ice (Christner et al., 2001). zfIIRht16 shows the highest sequence similarity to Agrococcus jenensis (AJ717350), from nonsaline alkaline environment (Tiago et al., 2004). Sequence zf-IIRlt1 is 97\% identical to that of uncultured actinomycete (AB002635), retrieved from sea mud of the Mariana Trench (Takami et al., 1997). zf-IIRlt3 has Planomicrobium chinense (AJ697862) from coastal sediments (Dai et al., 2005) as the nearest neighbor, with $98 \%$ sequence identity. Other culturable bacteria with different ARDRA patterns and recovered from Sample No. II are related to soil or other natural habitats, indicating their local or regional continental sources. Sequence zf-IIPht24 is most similar to $16 \mathrm{~S}$ rRNA sequences of the nickel resistance soil bacteria (Abou-Shanab et al., unpublished). Sequence zf-IIRht 4 is associated with that of Actinobacterium PB90-5 (AJ229241), from bulk soil (Chin et al., 1999). Sequences zf-IIRht17 is $99 \%$ identical to that of uncultured gamma proteobacterium Bioluz K32 (AF324537), from natural habitats (Sander et al., 2001). zf-IIRlt12 is clustered with Streptomyces sp. 80117 (AY996827), retrieved from North Hebei (Xiong et al., unpublished), with $98 \%$ identity. This is consistent with the wet deposition dominated by marine air masses and dry deposition dominated by local continental air masses during monsoon seasons in the Himalayan region (Kang et al., 2000). Only two culturable bacteria (zf-IVRht8 and zf-IVRht11) were different from those of the other 3 samples in ARDRA patterns among isolates from Sample No. IV deposited in winter (Fig. 4). Both are clustered with the genus Methylobacterium, ubiquitous in terrestrial habitats including soil, dust, etc. (Green, 1992), implying that sources of these two bacteria are associated solely with continental environment. Therefore, according to the results of RFLP analysis and $16 \mathrm{~S}$ rRNA sequencing with the isolates, Culturable bacteria deposited during monsoon period originate from either marine air masses and/or continental air fluxes, resulting in more species diversity. Whereas those deposited in winter are only from continental environment, resulting in less species diversity. Therefore, species diversity of the recovered bacteria and their possible sources based on $16 \mathrm{~S}$ rRNA sequence are consistent with the climate in the Himalaya being dominated by the Indian Monsoon in sum-
Table 4. Sample frequency of Chi-Square test.

\begin{tabular}{llll}
\hline Samples & Observed N & Expected N & Residual \\
\hline I & 10 & 7.0 & 3.0 \\
II & 15 & 7.0 & 8.0 \\
III & 1 & 7.0 & -6.0 \\
IV & 2 & 7.0 & -5.0 \\
\hline
\end{tabular}

mer and by westerly cyclonic activities in winter (Thompson et al., 2000). However, it is pretty cursory to identify sources of the recovered bacteria only from $16 \mathrm{~S}$ rRNA sequences. More experiments on samples from both the Himalayan and the other Tibetan glaciers are currently performed in order to explore our initial reasonable but somewhat immature conclusions because here we have only four samples to focus on.

\section{Conclusions}

The concentrations of culturable bacteria in the ER glacier are among the concentration level of the polar region that are two orders of magnitude lower than that of the other Tibetan ice cores. This is coincident with the different environmental conditions between the southern and northern part of the Tibetan plateau. In the ER glacier, larger amount of culturable bacteria were deposited in spring, when much dust is transported into the ice. But a greater diversity of culturable bacteria was deposited in summer, when the implied bacterial sources according to $16 \mathrm{~S}$ rRNA sequences were both the deposition of Indian monsoon air masses and the regional or local mineral aerosol. Therefore, we suggest a fingerprint of atmospheric circulation in the microorganisms isolated from Himalayan glacier ice. Our work expands knowledge of spatial and seasonal microbes in the Tibetan glaciers, but in the absence of sufficient samples, a more thorough study is required to better understand the correlation between microorganisms and their living environment.

Acknowledgements. We thank Editor T. W. Lyons and two anonymous referees for their helpful comments. This work was supported by the National Natural Science Foundation of China (90411003, 40576001, 40121101) and the Chinese Academy of Sciences (KZCX3-SW-344 and 100 Talents Project).

Edited by: T. W. Lyons

\section{References}

Abyzov, S. S., Mitskevich, I. N., and Poglazova, M. N.: Micro?ora of the deep glacier horizons of central Antarctica, Microbiology (Moscow), 67, 66-73, 1998. 
Altschul, S. F., Gish, W., Miller, W., Myers, E. W., and Lipman, D. J.: Basic local alignment search tool, J. Mol. Biol., 215, 403410, 1990.

Brinkmeyer, R., Knittel, K., Jurgens, J., Weyland, H., Amann, R., and Helmke, E.: Diversity and Structure of Bacterial Communities in Arctic versus Antarctic Pack Ice, Appl. Environ. Microbiol., 69, 6610-6619, 2003.

Bryson, R. A.: Air stream climatology of Asia. In: Proceedings of the International Symposium on the Qinghai-Xizang Plateau and Mountain Meteorology, American Meteorological Society, Boston, MA, 604-617, 1986.

Castello, J. D., Rogers, S. O., Starmer, W. T., Catranis, C. M., Ma, L., Bachand, G. D., Zhao, Y., and Smith, J. E.: Detection of tomato mosaic tobamovirus RNA in ancient glacial ice, Polar Biol., 22, 207-212, 1999.

Chin, K. J., Hahn, D., Hengstmann, U., Liesack, W., and Janssen, P. H.: Characterization and identification of numerically abundant culturable bacteria from the anoxic bulk soil of rice paddy microcosms, Appl. Environ. Microbiol., 65, 5042-5049, 1999.

Christner, B. C., Mosley-Thompson, E., Thompson, L. G., Zagorodnov, V., Sandman, K., and Reeve, J. N.: Recovery and identification of viable bacteria immured in glacial ice, Icarus, 144, 479-485, 2000.

Christner, B. C., Mosley-Thompson, E., Thompson, L. G., and Reeve, J. N.: Isolation of bacteria and 16S rRNAs from Lake Vostok accretion ice, Environ. Microbiol., 3, 570-577, 2001.

Christner, B. C.: Detection, recovery, isolation, and characterization of bacteria in glacial ice and Lake Vostok accretion ice. Ph. D. theis. The Ohio State University, Columbus, 2002.

Dai, X., Wang, Y. N., Wang, B. J., Liu, S. J., and Zhou, Y. G.: Planomicrobium chinense sp. nov., isolated from coastal sediment, and transfer of Planococcus psychrophilus and Planococcus alkanoclasticus to Planomicrobium as Planomicrobium psychrophilum comb. nov. and Planomicrobium alkanoclasticum comb. nov, Int. J. Syst. Evol. Microbiol., 55, 699-702, 2005.

Dancer, S. J., Shears, P., and Platt, D. J.: Isolation and characterization of coliforms from glacial ice and water in Canada's High Arctic, J. Appl. Microbiol., 82, 597-609, 1997.

Green, P. N.: The genus Methylobacterium: The Prokaryotes, 2nd ed., edited by: Balows, A., Truper, H. G., Dworkin, M., Harder, W., and Schleifer, K.-H., 2342-2349, New York, Springer-Verlag Holland, MA, 1992.

Groudieva, T., Kambourova, M., Yusef, H., Royter, M., Grote, R., Trinks, H., and Antranikian, G.: Diversity and cold-active hydrolytic enzymes of culturable bacteria associated with Arctic sea ice, Spitzbergen, Extremophile, 8, 475-488, 2004.

Li, G.: Dynamic Meteorological of the Tibetan Plateau, China Meteorological Press, Beijing, 2002 (In Chinese).

Kang, S., Wake, C. P., Qin, D., Mayewski, P. A., and Yao, T.: Monsoon and dust signals recorded in the Dasuopu firn core, central Himalayas, J. Glaciol., 46, 222-226, 2000.

Kang, S. C., Mayewski, P. A., Qin, D. H., Yan, Y. P., Hou, S. G., Zhang, D. Q., Ren, J. W., and Kreutz, K. J.: Glaciochemical records from a Mt. Everest ice core: relationship to atmospheric circulation over Asia, Atmos. Environ., 36, 3351-3361, 2002.

Kumar, S. and Tamura, K. M. N.: MEGA molecular evolutionary genetics analysis, version 1.01. Pennsylvania State University, University Park, 1993.

Marinoni, A., Polesello, S., Smiraglia, C., and Valsecchi, S.: Chem- ical composition of freshsnow samples from the southern slope of Mt. Everest region (Khumbu-Himal region, Nepal), Atmos. Environ., 35, 3183-3190, 2001.

Priscu, J. C., Fritsen, C. H., Adams, E. E., Giovannoni, S. J., Paerl, H. W., McKay, C. P., Doran, P. T., Gordon, D. A., Lanoil, B. D., and Pinckney J. L. Perennial Antarctic lake ice: an oasis for life in a polar desert, Science, 280, 2095-2098, 1998.

Priscu, J. C., Adams, E. E., Lyons, W. B., Voytek, M. A., Mogk, D. W., Brown, R. L., McKay, C. P., Takacs, C. D., Welch, K. A., Wolf, C. F., Kirshtein, J. D., and Avci, R.: Geomicrobiology of subglacial ice above Lake Vostok, Antarctica, Science, 286, 2141-2144, 1999.

Sander, M. and Schmieger, H.: Method for host-independent detection of generalized transducing bacteriophages in natural habitats, Appl. Environ. Microbiol., 67, 1490-1493, 2001.

Takami, H., Inoue, A., Fuji, F., and Horikoshi, K.: Microbial flora in the deepest sea mud of the Mariana Trench, FEMS Microbiol. Lett., 152, 279-285, 1997.

Tang, M.: Formation, evolution and variability characteristics of Qinghai-Tibetan Plateau Monsoon. In: Contemporary climatic variations over Qinghai-Tibetan Plateau and their influences on environments (ed. Tang, M., Chen, G., Lin, Z.), Guangdong Sciences and Technology Press, Guangzhou, 161-182, 1998.

Thompson, J. D., Gibson, T. J., Plewniak, F., Jeanmougin, F., and Higgins, D. G.: The CLUSTAL-X Windows interface-flexible strategies for multiple sequence alignment aided by quality analysis tools, Nucleic Acids Res., 24, 4876-4882, 1997.

Thompson, L. G., Yao, T. D., Mosley-Thompson, E., Davis, M. E., Henderson, K. A., and Lin, P.-N.: A high-resolution millennial record of the South Asian Monsoon from Himalayan ice cores, Science, 289, 1916-1919, 2000.

Tiago, I., Chung, A. P., and Veríssimo, A.: Bacterial diversity in a nonsaline alkaline environment: heterotrophic aerobic populations, Appl. Environ. Microbiol., 70, 7378-7387, 2004.

Tian, L., Masson-Delmotte, V., Stievenard, M., Yao, T., and Jouzel, J.: Tibetan plateau summer monsoon northward extent revealed by measurements of water stable isotopes, J. Geophys. Res., 106(D22), 28 081-28 088, 2001.

Tian, L., Yao, T., Schuster, P. F., White, J. W. C., Ichiyanagi, K., Pendall, E., Pu, J., and Yu, W.: Oxygen-18 concentrations in recent precipitation and ice cores on the Tibetan Plateau, J. Geophys. Res., 108(D9), 4293-4302, 2003.

Wake, C. P., Dibb, J. E., Mayewski, P. A., Li, Z. Q., and Xie, Z. C.: The chemical composition of aerosols over the eastern Himalayas and Tibetan Plateau during low dust periods, Atmos. Environ., 28, 695-704, 1994.

Willerslev, E., Hansen, A. J., Christensen, B., Steffensen, J. P., and Arctander, P.: Diversity of Holocene life forms in fossil glacier ice, Proc. Natl. Acad. Sci., 96, 8017-8021, 1999.

Wu, G., Yao, T., Thompson, L. G., and Li, Z.: Microparticle record in the Guliya ice core and its comparison with polar records since the last interglacial, Chin. Sci. Bull., 49(6), 607-611, 2004.

Wu, G. and Zhang, Y.: Tibetan Plateau forcing and the monsoon onset over South Asia and the South China Sea, Mon. Wea. Rev., 126, 913-927, 1998.

Xiang, S. R., Yao, T. D., An, L. Z., Xu, B. Q., and Wang, J. X.: 16S rRNA Sequences and Differences in Bacteria Isolated from the Muztag Ata Glacier at Increasing Depths, Appl. Environ. Microbiol., 71, 4619-4627, 2005a. 
Xiang, S. R., Yao, T. D., An, L. Z., Wu, G. J., Xu, B. Q., Ma X. J., Li, Z., Wang J. X., and Yu, W. S.: Vertical quantitative and dominant population distribution of the bacteria in the Muztagh Ata ice core, Sci. China, D48(10), 1728-1739, 2005b.

Xiao, C. D., Kang, S. C., Qin, D. H., Yao, T. D., and Ren, J. W.: Transport of atmospheric impurities over the Qinghai-Xizang (Tibetan) Plateau as shown by snow chemistry, J. Asian Earth Sci., 20, 231-239, 2002.

Yao, T., Wu, G., Pu, J., Jiao, K., and Huang, C.: Relationship between calcium and atmospheric dust recorded in Guliya ice core, Chin. Sci. Bull., 49, 706-710, 2004.

Yao, T., Xiang, S., Zhang, X., Wang, N., and Wang, Y.: Microorganisms in the Malan ice core and their relation to climatic and environmental changes, Global Biogeochem. Cycles, 20, GB1004, doi:10.1029/2004GB002424, 2006.
Zhang, D. Q., Qin, D. H., Hou, S. G., Kang, S. C., Ren, J. W., and Mayewski. P. A.: Climatic significance of record from an $80.36 \mathrm{~m}$ ice core in the East Rongbuk Glacier, Mount Qomolangma (Everest), Sci. China, D48(2), 266-272, 2005.

Zhang, X. J., Yao, T. D., Ma, X. J., and Wang, N. L.: Analysis of the characteristics packed in the ice core of Malan Glacier, Tibet, China, Sci. China, D44 (suppl.), 369-374, 2001.

Zhang, X. J., Ma, X., Yao, T., and Zhang, G.: Diversity of $16 \mathrm{~S}$ rRNA and environmental factor influencing bacteria in Malan ice core, Chin. Sci. Bull., 48 (11), 1146-1150, 2003.

Zhou, J. Z., Bruns, M. A., and Tiedje, J. M.: DNA recovery from soils of diverse composition, Appl. Environ. Microbiol., 62, 316322, 1996.

Zhou, S. Meteorology and Climatology (3rd edit). High Education Press, Beijing. 1997 (In Chinese). 